\title{
Ground Water Level Fluctuation and Its Impact on Irrigation Cost at Jessore Sadar of Bangladesh
}

\author{
G. M. Abdur Rahman', Md. Jamal Faruque², Mehedi Hashan Sohel ${ }^{3}$, Abu Sayed ${ }^{4}$, * \\ ${ }^{1}$ Department of Agricultural Extension (DAE), Jhenaidha, Bangladesh \\ ${ }^{2}$ Bangladesh Agricultural Development Corporation (BADC), Khulna, Bangladesh \\ ${ }^{3}$ Department of Soil Science, EXIM Bank Agricultural University Bangladesh, Chapainawabgonj, Bangladesh \\ ${ }^{4}$ Department of Agricultural Engineering, EXIM Bank Agricultural University Bangladesh, Chapainawabgonj, Bangladesh
}

\section{Email address:}

rahman82bd@gmail.com (G. M. A. Rahman),mjfaruque@gmail.com (Md. J. Faruque), mehedibau113@gmail.com (M. H. Sohel), abu_982@yahoo.com (A. Sayed)

${ }^{*}$ Corresponding author

\section{To cite this article:}

G. M. Abdur Rahman, Md. Jamal Faruque, Mehedi Hashan Sohel, Abu Sayed. Ground Water Level Fluctuation and Its Impact on Irrigation Cost at Jessore Sadar of Bangladesh. Agriculture, Forestry and Fisheries. Vol. 5, No. 3, 2016, pp. 37-42. doi: 10.11648/j.aff.20160503.12

Received: April 16, 2016; Accepted: May 3, 2016; Published: May 25, 2016

\begin{abstract}
The study was conducted to access the ground water level fluctuation and impacts on irrigation cost of Jessore sadar and Jhikargacha upazilla. Questionnaire survey and Key Information Interview (KII) were done to collect primary data from local farmers, pump operator, DAE officials and personnel from BADC. The secondary data were collected from BADC. From study area it was found that the Maximum ground water level varies 5.1 to $9.35 \mathrm{~m}$ at the month of April to May where minimum ground water level varies 1.15 to $4.88 \mathrm{~m}$ at October to November from 2004 to 2013. The trends of maximum fluctuation level increased 5.65 to $9.35 \mathrm{~m}$ and 5.1 to $8.36 \mathrm{~m}$ at Jessore sadar and Jhikargacha respectively, in April 2004 to April 2013. From the study it was also found that ground water level fluctuation mostly affect the STW irrigation where $100 \%$ of STW at the study area have faced pump failure and for the remedial measure $100 \%$ taken measure to deep set method. Pumping hour for both STW and DTW has increased in 2013 than 2009. It was found $99 \%$ of the respondents were aware of lowering of ground water level in their agriculture fields, $85 \%$ of farmers complained that they did not get enough water during the dry season irrigation period. Over $95 \%$ of the respondents were well aware about excessive pumping. Most important thing was that $95 \%$ of the respondents replied that they didn't get training for irrigation and have not enough knowledge for irrigation efficiency and the crop water use. To obtain desired economic benefits from groundwater resource, the management of ground water is essential.
\end{abstract}

Keywords: Ground Water Table, Fluctuation, Irrigation, Water Quality, Jessore

\section{Introduction}

Groundwater is the main source of irrigation which is an important parameter to increase crops production. But the amount of extraction is increased day by day due to increase of population, food insecurity, and poor water management and below average rainfall is putting unprecedented pressure on groundwater [1]. With the continuous abstraction, the water table in many areas started declining and the STWs were no more capable of pumping under suction mode during the peak irrigation period. It has been observed that ground water fluctuate mostly on dry season as because of no rainfall at that time. So the lowering of the water table lead to the drying up of more shallow wells, requiring deeper tube wells, and increased pumping cost. As per report of the International Rice Research Institute (IRRI), irrigation efficiency in Bangladesh is the lowest in the region, where the cost of irrigation is $\$ 117.60$ per hectare compared to \$25.58 in India, \$17.94 in Thailand and \$17.98 in Vietnam. If water was managed properly, Bangladesh could save additional amount of money equivalent to one-sixth of the total Bangladesh Budget for the Fiscal Year (FY) of 2003-04 (USD 8,962 million) [2] and also similar to the ADP budget of Bangladesh for FY 2009-10 (USD 4072 million). 
A recent study shows that groundwater level in some areas of Bangladesh falls between 5-10 $\mathrm{m}$ in dry season and most of the tubewells fail to lift sufficient water [3]. Researchers and policymakers are advocating sustainable development as the best approach to today's and future water problems [4, 5]. They shows that frequent shortage of water in the region has had impacts that can be ranged as economical, social and environmental [6, $7 \&$ \& $]$. Hossain [9] reported that hundreds of shallow and hand tube wells become inoperative due to over exploitation of groundwater, lack of adequate groundwater recharge during wet season and low specific yield of upper aquifers. This situation can be exacerbated by 2030 when water demand will be doubled due to expected increase in dry season agriculture. Now time has come to think over the issue to meet the challenge. Some works already have been done in different parts of Bangladesh. Now it is needed to conduct location specific comprehensive study for realistic assessment of ground reserves and their use at present condition. For this purpose a study was conducted to assess the ground water level fluctuation and impacts on irrigation cost for planning groundwater resource in this area.

\section{Methodology}

\subsection{Study Area}

The study area lies in the physiographic unit of high Ganges floodplain. It lies under the AEZ no. 11 (High Ganges river floodplain). The land is very fertile. The area is most suitable for rice, vegetables and upland crops. A total land area of this district is 7287711 acre where cultivable land is 415635 acre. Of the cultivable land there is about $70 \%$ under irrigation and about $80 \%$ of total irrigated area is covered by ground water irrigation systems [10]. This is one of the large irrigation districts in Bangladesh. Average maximum temperatures vary from about $25^{\circ} \mathrm{C}$ to $35^{\circ} \mathrm{C}$ in April and the minimum temperature in varies from $12^{\circ} \mathrm{C}$ to $14^{\circ} \mathrm{C}$ in late December and early January. The maximum rainfall is recorded in August and September.

\subsection{Data Collection}

Jessore sadar and Jhikargacha upazilla were selected purposively from the study area. Secondary data for groundwater table was collected from BADC. For each upazilla 5 observation wells were selected randomly out of 9 at Jhikargacha and 10 at Jessore sadar. Six (6) questionnaire survey and (3) Key Information Interview (KII) were conducted to collect primary data from local farmers, pump operator, DAE officials and personnel from BADC. Semi structured questionnaire survey used to assess the impacts underline the ground water fluctuation on irrigation system, costing of irrigation, farmers concept on ground water fluctuation and the problems faced in this regards, their thinking to reasons behind the ground water fluctuation, crop diversification, production etc.

\section{Results and Discussion}

\subsection{Ground Water Level Fluctuation}

Average yearly ground water level fluctuation of Jessore sadar and Jhikargacha are shown in Table 1. The table shows that the lowest average ground water level fluctuation were $3.48 \mathrm{~m}$ in Taposhidanga of Jessore sadar and $3.94 \mathrm{~m}$ in Padmapukur of Jhikargacha in 2004. The maximum ground water level depths were $6.41 \mathrm{~m}$ in Ichhali of Jessore sadar and $6.56 \mathrm{~m}$ in Bish Hari, Jhikargacha during 2010.

Table 1. Average yearly ground water level fluctuation of Jessoresadar and Jhikargacha.

\begin{tabular}{|c|c|c|c|c|c|c|c|c|c|c|c|}
\hline \multicolumn{2}{|c|}{ Name of the place } & \multicolumn{10}{|c|}{ Yearly average ground water level fluctuation (m) } \\
\hline Upazilla & Union & 2004 & 2005 & 2006 & 2007 & 2008 & 2009 & 2010 & 2011 & 2012 & 2013 \\
\hline \multirow{4}{*}{$\begin{array}{l}\text { Jessore } \\
\text { Sadar }\end{array}$} & Tapaswidanga & 4.50 & 6.10 & 5.92 & 6.02 & 4.48 & 6.36 & 5.72 & 6.46 & 6.13 & 6.87 \\
\hline & Ichhali & 3.96 & 6.00 & 5.50 & 6.53 & 4.55 & 6.31 & 5.81 & 6.63 & 6.11 & 7.07 \\
\hline & Bijoynagar & 3.90 & 5.98 & 5.29 & 5.99 & 4.46 & 6.17 & 5.70 & 6.51 & 6.17 & 7.02 \\
\hline & Shekhati & 4.15 & 6.07 & 4.67 & 5.26 & 4.46 & 6.26 & 5.63 & 6.49 & 6.09 & 6.97 \\
\hline \multirow{5}{*}{ Jhikargacha } & Bankara & 3.97 & 4.14 & 4.38 & 4.17 & 4.11 & 4.93 & 6.13 & 5.51 & 5.99 & 5.96 \\
\hline & BishHari & 4.15 & 4.99 & 4.92 & 4.83 & 4.74 & 5.38 & 6.56 & 5.92 & 6.07 & 5.97 \\
\hline & Padma Pukuria & 3.94 & 4.91 & 4.92 & 4.92 & 4.76 & 5.28 & 6.30 & 5.68 & 6.16 & 6.13 \\
\hline & Mohammandpur & 4.41 & 5.37 & 5.34 & 5.17 & 4.83 & 5.41 & 6.44 & 5.82 & 6.06 & 5.93 \\
\hline & Shankarpur & 4.33 & 5.16 & 5.71 & 4.87 & 4.62 & 5.36 & 6.50 & 5.55 & 6.12 & 6.04 \\
\hline
\end{tabular}

Figure 1 shows the average ground water level fluctuation in the observation well at Jessore sadar and Jhikargacha over the time period. The trends of average ground water level increased gradually from 2004 to 2006 where except in Sheikhati mouza observation well where it is shown abrupt increased from 2004 to 2005 and then gradually decreased to 2008. After 2008 the average ground water level increased rapidly and going to the peak at 2010 in both upazilla and then small decreased to 2013 . 


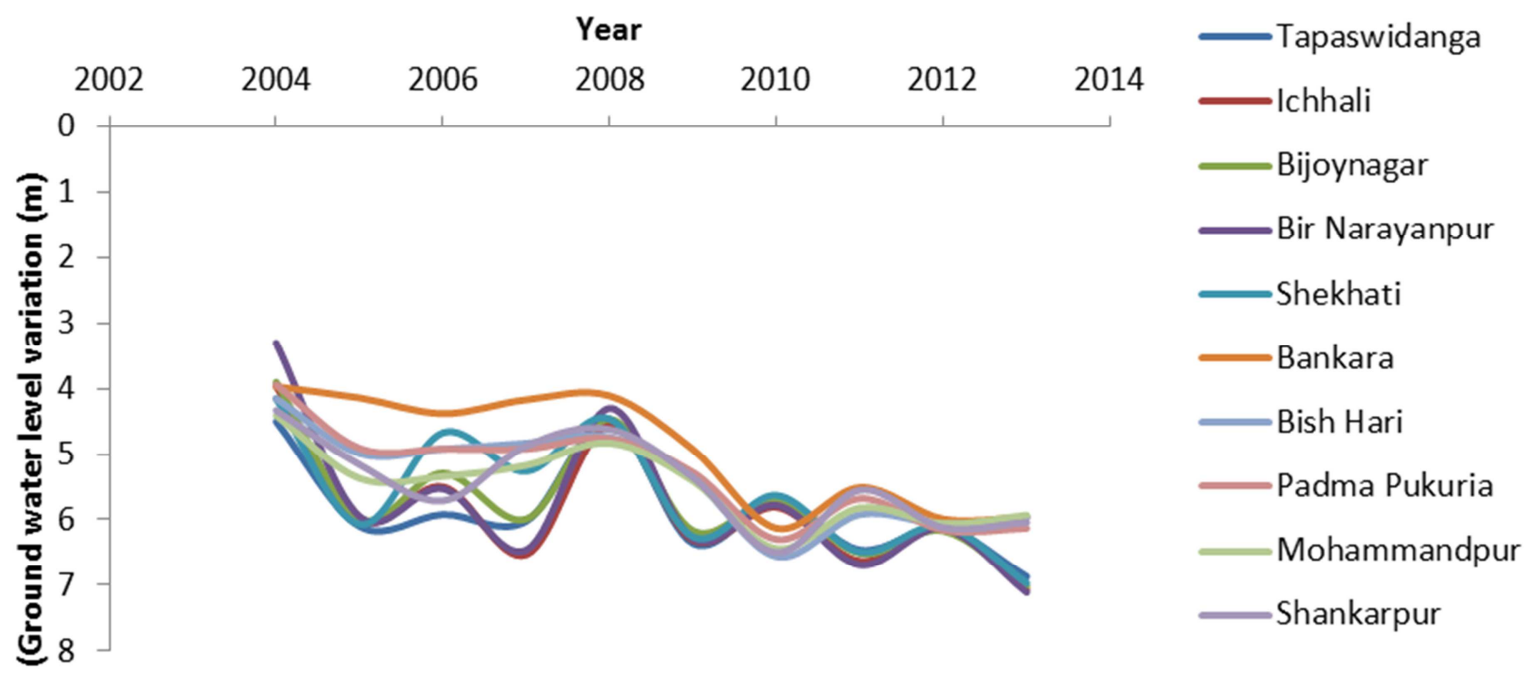

Figure 1. Average ground water level fluctuation trends over the time period in Jessoresadar and Jhikargacha.

Figure 1 also shows that groundwater level variation (maximum water level-minimum water level) in the observation well of Jessore sadar and Jhikargacha respectively. It was seen that groundwater level variation ups and down in consecutive year except at Jhikargacha where shown rapid increase from 2004 to 2006 and rapid decrease to 2007 and then follows the same. But from the analysis it was found that groundwater level variation more increase at Jessore sadar where minimum variation in 2004 and maximum in 2013 for all of the observation well. However in Jhikargacha, groundwater level variation shows somewhat different and it was minimum in 2004 and then variation abruptly increase to 2006, and that was the peak variation of all observation wells. In Jessore sadar, minimum water level variation $3.3 \mathrm{~m}$ at Bir Narayanpur in 2004 and maximum $7.11 \mathrm{~m}$ in 2013 at the same well. As well as in Jhikargacha,2.5 $\mathrm{m}$ at Padma Pukur in 2004 and $6.51 \mathrm{~m}$ at Bankara in 2006.

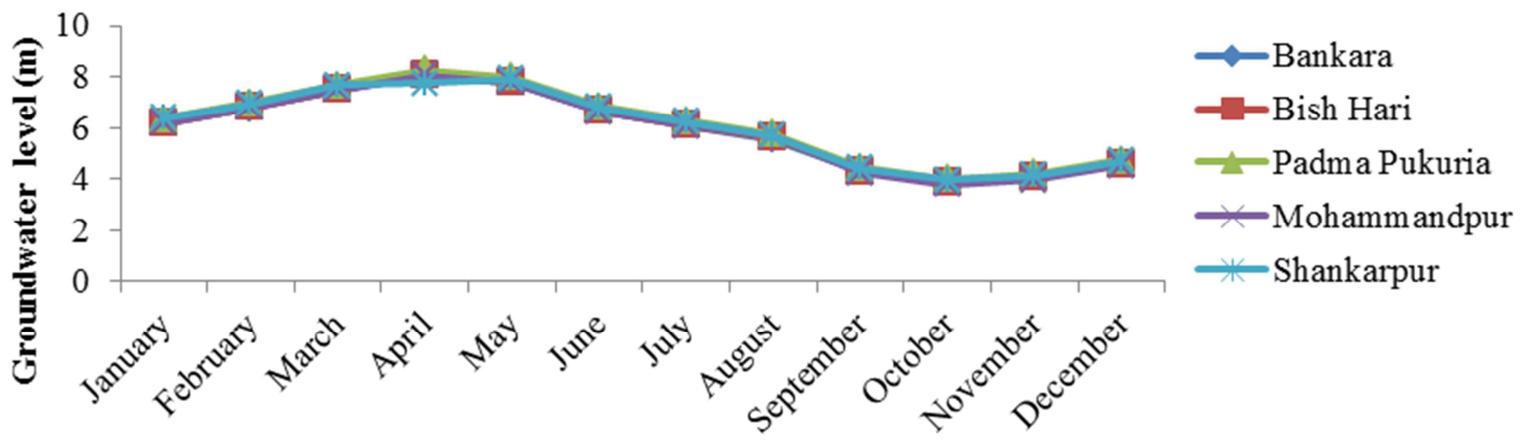

Figure 2. Seasonal variation of ground water level at Jhikargacha in 2013.

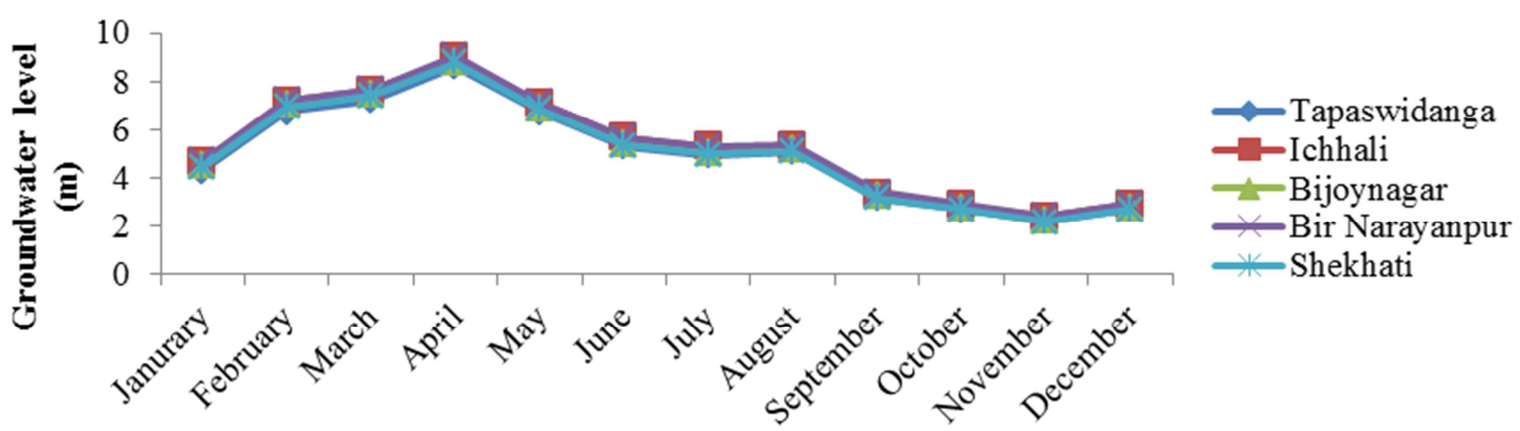

Figure 3. Seasonal variation of ground water level at Jessore sadar in 2013.

Figure 2 and 3 shows the seasonal variation of groundwater level in the observation well at Jhikargacha and Jessore sadar in 2013 respectively. From seasonal variation analysis in the experimental well at both areas were shown 2 peak levels where as maximum ground water level lies in the month of March to April and minimum ground water level in the month of October to November. In the study area most of ground water withdrawal was occurred in dry months starting 
from January and continues up to May and in June some cases in dry season. During the period the recharge was almost nil, the rate of evaporation and evapotranspiration was high. As a result the water level was declined sharply and reaches to maximum depth in April. In rainy season ground water level decrease in correspondence to the ground surface as because during this time begins to recharge to the underground storage. At the same time it was occurred minimum withdrawal of ground water for irrigation, and high relative humidity in the atmospheric reduces the rate of evaporation and evapotranspiration. All these cause a gradual increase in ground water reservoir which was reflected by the change of water table and it was going to minimum in the end of rainy period month of October to November.

\subsection{Factors Affect to Ground Water Level Fluctuation}

\subsubsection{Rainfall}

The table 2 shows that the average rainfall trends over the time period of 2004 to 2013 at Jessore sadar and Jhikargacha. The average rainfalls in 2004 to 2005 were decreased suddenly and then gradually increased to 2007 and after then decreased to 2012. From analysis of average ground water level and average rainfall it was found that ground water level fluctuation is related to rainfall as because rainfall is most important factor for ground water recharge. When the rainfall was higher the ground water level was lower. Figure 4 shows the seasonal rainfall variations in Jessore during 2004, 2009 and 2013.

Table 2. Average ground water table, rain fall and river flow of Jessore sadar and Jhikargacha.

\begin{tabular}{|c|c|c|c|c|c|c|c|c|c|c|}
\hline \multirow{2}{*}{$\begin{array}{l}\text { Para } \\
\text { meter }\end{array}$} & \multicolumn{10}{|l|}{ Years } \\
\hline & 2004 & 2005 & 2006 & 2007 & 2008 & 2009 & 2010 & 2011 & 2012 & 2013 \\
\hline GWT & 4.340 & 5.398 & 5.545 & 4.741 & 4.541 & 5.687 & 6.036 & 5.812 & 5.736 & 5.154 \\
\hline Rainfall & 207.50 & 125.1 & 147.2 & 177.6 & 161.0 & 133.7 & 103.3 & 94.4 & 89.6 & 144.5 \\
\hline
\end{tabular}

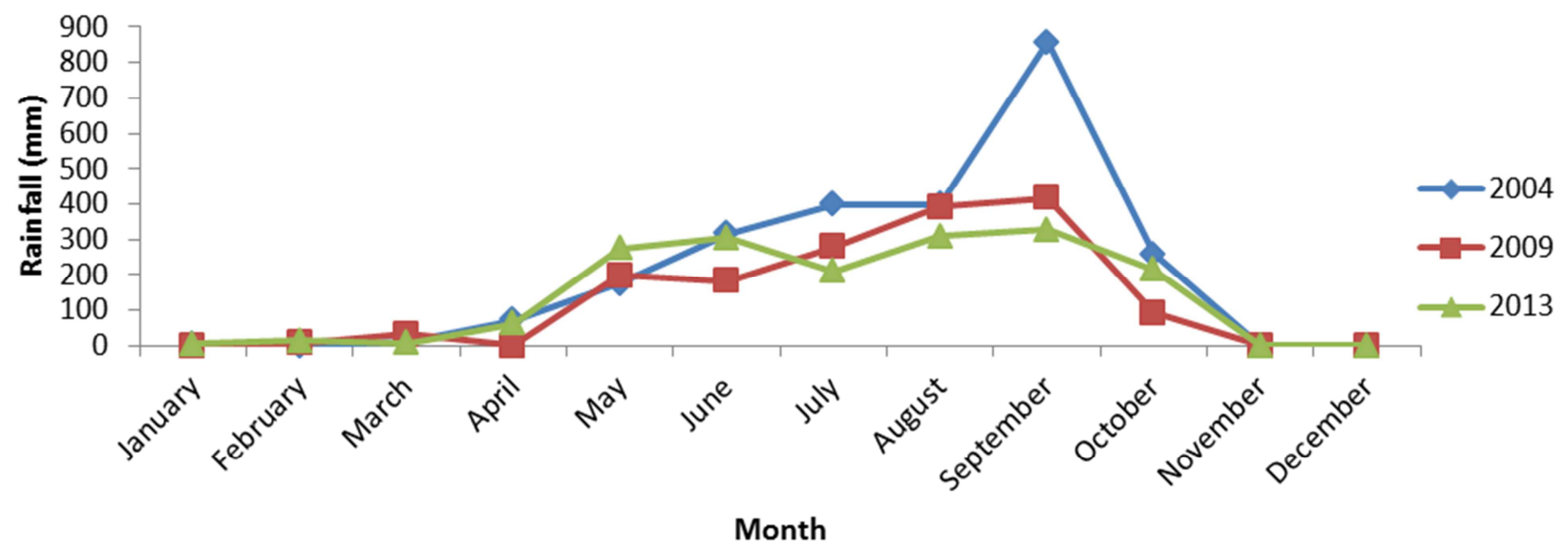

Figure 4. Seasonal rainfall variations in Jessore.

\subsubsection{River Flow}

Jhikargacha upazilla lies in catchment area of river Kapatakha. Table 2 shows that the average river flow discharge varies during time period 2006 to 2013 and it is highest in 2008 and the rapidly decrease to 2010 after then increase gradually with ups and down. Table 2 also shows that ground water level fluctuation trends have shown significant in aspect of average river flow discharge in 2010 highest in ground water level and then its gradually decrease according to the river flow with ups and down.

\subsubsection{Welling Intensity}

According to table 3 it found that DTW were increased steadily in both areas and it were 277 to 289 in 2005 and 297 to 337 in 2013 respectively at Jessore sadar and Jhikargacha. In case of STW, it was increased 8220 to 8917 from 2005 to 2013 in Jessore sadar. But in Jhikargacha the number was increased 8383 to 8448 from 2005 to 2009 after then decreased to 8175 in 2013 . From the study it was seen that the average irrigable land was about 5 acre for STW and 25 acre for DTW. In consideration of soil characteristics the command area would be 8-10 acre for STW and 45-50 acre for DTW. In time correspondence the number of irrigation equipment was increased but the irrigated land was remaining same. So the water withdrawn from ground water was increased that ultimately affects to ground water level and in dry season during April-May it reaches peak. Irrigation practice in the study area is mostly from ground water source, a greater portion of which is being abstracted through STWs Shahid [11] and Shahid and Behrawan [12] stated that the contribution of ground water has increased from $41 \%$ in $1982-83$ to $77 \%$ in $2006-07$ and surface water has declined accordingly.

Table 3. Numbers of DTW and STW over the time period.

\begin{tabular}{lllllll}
\hline \multirow{2}{*}{ Study Area } & DTW & \multicolumn{7}{c}{ STW } \\
\cline { 2 - 7 } & $\mathbf{2 0 0 4}$ & $\mathbf{2 0 0 9}$ & $\mathbf{2 0 1 3}$ & $\mathbf{2 0 0 4}$ & $\mathbf{2 0 0 9}$ & $\mathbf{2 0 1 3}$ \\
\hline Jessore sadar & 277 & 292 & 297 & 8220 & 8331 & 8917 \\
Jhikargacha & 289 & 322 & 337 & 8383 & 8448 & 8175 \\
\hline
\end{tabular}




\subsection{Correlation GWTD, Rainfall and River Flow}

Table 4 shows correlation between GWTD and Rainfall in Jessore sadar. From the statistical analysis it was found negative correlation between rainfall and GWTD where the statistical correlation value is 0.900 that is strongly correlated and shows highly significant (Annex A3). It means if the rainfall increases then the GWTD decreases because rain water infiltrates to the earth and recharge to ground water table that leads to decrease depth of GWT. Table also shows correlation among GWTD, Rainfall and River flow in
Jhikargacha. From the statistical analysis it was found negative correlation between GWTD and rainfall where statistical value is 0.822 that is also strongly correlated and shows highly significant. In case of GWTD and river flow, it was also seen negative correlation and the value is 0.535 that means medium correlation and it also shows significant but lesser significant than rainfall. In that cases if the river flow increases then there has occurred recharge to GWT which leads to decrease depth of GWT also. So rainfall is the important factor in both areas for GWT recharging.

Table 4. Correlation between GWTD and Rainfall in Jessore sadar.

\begin{tabular}{lllll}
\hline & Jessore sadar & & Jhikargacha & \\
\hline & GWT & Rainfall & GWT (Avg) & Rainfall \\
\hline GWT & 1 & & 1 & \\
Rainfall & -0.900082467 & 1 & -0.822335596 & 1 \\
River Flow & - & - & -0.535602603 & 0.456343195 \\
\hline
\end{tabular}

\subsection{Ground Water Level Fluctuation and Impact on Irrigation}

\subsubsection{Impact on Pumping Systems}

In dry season particularly during April to May ground water level fluctuation was high which gone $9.3 \mathrm{~m}$ maximum at Jessore sadar in April 2013 and $8.3 \mathrm{~m}$ at Jhikargacha at April 2013 (Fig 2 and 3). The fluctuation level was highly significant for the centrifugal pump because of in practical ground water can be withdrawn within $7.5 \mathrm{~m}$. From the observation it was found that $100 \%$ of STW at that area have faced pump failure and for the remedial measure 100\% taken measure to deep set method. In deep set method, pump head was lowered 2.5 to $3 \mathrm{~m}$ under the ground surface by digging out within the bore. About $60 \%$ DTW were faced unable to withdraw of water. The reason here mentioned for instance of DTW that those tube well were installed during 1980 to 1990 , at that time pumping head was designed for 12 to 16 $\mathrm{m}$. For these circumstances well pumping has created drawdown that goes 1 to $2 \mathrm{~m}$ and causes failure to discharge. For that situations $100 \%$ cases adjusted pump dynamic head with lowering of the pump into the casing. It was seen that the trends of maximum fluctuation level increasing $4.5 \mathrm{~m}$ in 2004 and increased to $9.3 \mathrm{~m}$ in 2013 at Jessore sadar where as for Jhikargacha it was $4.5 \mathrm{~m}$ in 2004 and $9.6 \mathrm{~m}$ in 2013. So both the cases it was alarming for the irrigation in relating to irrigation pump because for STW method used $85 \%$ for irrigation sector. Moreover, it associated to increase cost in terms of pumping system management and also reduced the irrigation coverage. It was seen that for Deep tube well that are installed during 1980 to 1985 by BADC also facing pump failure because at that time turbine was set in the depth of 10 $\mathrm{m}$ to $15 \mathrm{~m}$. In that cases withdrawing water from the well creating drawdown which going beyond that level. For instance BADC, made the correction by lowering the pump head.

\subsubsection{Impact on Irrigation}

From the study it was found that irrigation pump mostly used in during Boro-season and the peak use in the month of March-April. Table 5 shows the average pumping hour for DTW and STW respectively during 2013 and 2009. It was found pumping hour for DTW 1086 to 1256 and 655 to 922.5 for STW during period 2009 to 2013. During T-aman season the utilization of pump depends on rain. So over the time period pumping hour for both STW and DTW were increased. In addition irrigation costing was increased due to pump failure including deep set transplant for STW and pumping head adjustment for DTW. According to BADC and $\mathrm{DAE}$, there are no rules and regulation for irrigation in relating to irrigation system and for the water users. For this reason who are able to install pump getting pump without concern of regarding institutions.

Table 5. Average DTW and STW pumping hour.

\begin{tabular}{|c|c|c|c|c|c|}
\hline \multirow{2}{*}{ Crops season } & \multirow{2}{*}{ Month } & \multicolumn{2}{|c|}{ Average DTW pumping hour for 33 acre irrigated land } & \multicolumn{2}{|c|}{ Average STW pumping hour for 8.5 acre irrigated land } \\
\hline & & 2013 & 2009 & 2013 & 2009 \\
\hline \multirow{5}{*}{ Boro season } & January & 212 & 180 & 95.5 & 72 \\
\hline & February & 217 & 195 & 130 & 90 \\
\hline & March & 401 & 360 & 240.5 & 180 \\
\hline & April & 327 & 295 & 196 & 150 \\
\hline & May & 21 & 18 & 12.5 & 8 \\
\hline \multirow{4}{*}{ T-Aman Season } & August & 37 & 15 & 48 & 25 \\
\hline & October & 17 & 8 & 80 & 45 \\
\hline & November & 10 & 5 & 50 & 30 \\
\hline & Total hour & 1256 & 1086 & 922.5 & 655 \\
\hline
\end{tabular}




\section{Conclusion}

In conclusion the groundwater level fluctuation at the study area has shown significant to irrigation. Average groundwater level fluctuation and the maximum water level variation increases day by day putting pressure on irrigation system as well as irrigation costing in regards on pumping hour, command area and the irrigation management. Decreasing average precipitation, unusual nature of river water flow and increasing welling intensity greatly affect to groundwater level fluctuation at the study area. Moreover the lack of knowledge on efficient irrigation management and the crop water use also affect the groundwater level fluctuation. To obtain desired economic benefits from groundwater resource, the management of ground water is essential. The proper management of ground water resources requires adequate knowledge of the extent of the storage, the rate of discharge, the rate of recharge to ground water body and the use of economical withdrawal.

\section{References}

[1] N. C. Dey, S. K. Bala, A. K. M. Islam, M. A. Rashid, and M. Hossain, "A study on Sustainability of Groundwater Use for Irrigation in Northwest Bangladesh" The study was carried out with the support of the National Food Policy Capacity Strengthening Programme, Government of the People's Republic of Bangladesh, Dhaka, 2013.

[2] N. C. Dey, S. K. Bala, and H. Seiji, "Assessing the Economic Benefits of Improved Irrigation Management: A Case Study of Bangladesh" Journal of International Water Association, pp, 8, 2006.

[3] N. C. Dey, and A. R. M. Ali, "Changes in the Use of Safe Water and Water Safety Measures in WASH Intervention Areas of Bangladesh, a Midline Assessment" Working Paper, No. 27, BRAC-RED, Dhaka.573-84, 2010. Available at: http://www.iwaponline.com/wp/00806.
[4] D. P. Loucks, "Sustainable Water Resources Management" Journal of Water International, Vol. 25(1), pp. 3-11, 2000.

[5] X. Cai, C. Daene, M. Kinney, M. W. Rosegrant, "Sustainability Analysis for Irrigation Water Management: Concepts, Methodology, and Application to the Aral Sea region" Discussion Paper, No. 86, International Food Policy Research Institute, USA,2001.

[6] K. Takara, and S. Ikebuchi, 'Japan's 1994 Drought in Terms of Drought Duration Curve', Proceedings of the fifth symposium of Water Resources, pp. 467-477, 1997.

[7] A. K. Sajjan, A. B. Muhammed, and C. D. Nepal, 'Impact of 1994-95 Drought in the Northwest of Bangladesh through Questionnaire Survey', Proceedings of the 2nd annual paper meet of Agricultural Engineering Division, Institution of Engineers, Bangladesh, 31 May 2002.

[8] N. C. Dey, M. S. Alam, A. K. Sajjan, M. A. Bhuiyan, L. Ghose, Y. Ibaraki, and F. Karim, "Assessing Environmental and Health Impact of Drought in the Northwest Bangladesh", Journal of Environmental Science \& Natural Resources, 4(2), pp. 89-97, 2011.

[9] A. Hossain, "Groundwater Monitoring and Management" Pakistan Water Partnership (PWP), Islamabad, Pakistan, 2000.

[10] BADC, 'Statistical Report on Irrigation in Jessore', Bangladesh Agricultural Development Corporation (BADC), Ministry of Agriculture, Government of the People's Republic of Bangladesh, Dhaka, 2012.

[11] S. Shahid, "Spatial and Temporal Characteristics of Droughts in the Western part of Bangladesh", Hydrology Process, 22, pp. 2235-2247, 2008.

[12] S. Shahid, and H. Behrawan, "Drought Risk Assessment in the Western part of Bangladesh", Journal of Natural disaster, 46, pp. 391-413, 2008. 